\title{
New habitats, new menaces: Centaurea x kleinii (C. moncktonii x C. solstitialis), a new hybrid species between two alien weeds
}

\author{
C. T. ROCHÉ ${ }^{1} \&$ A. SUSANNA ${ }^{2}$ \\ ${ }^{1}$ P. O. Box 808, Talent, OR 97540, United States of America \\ ${ }^{2}$ Institut Botànic de Barcelona (CSIC-ICUB), Psg. del Migdia s/n., 08038 Barcelona, Spain \\ Author for correspondence: A. Susanna (asusanna@ibb.csic.es)
}

Received 15 September 2010; Accepted 15 October 2010

\begin{abstract}
New habitats, new menaces: Centaurea $x$ kleinii $(C$. moncktonii $x$ C. solstitialis), a new hybrid species between two alien weeds.- Anthropic alteration of habitat opens the door to the cohabitation of imported species that in their native range would never coexist. Centaurea solstitialis and Centaurea moncktonii are two invasive species whose natural distributions in Eurasia do not overlap. After introduction in North America, invasive spread led to overlapping distributions. Although the environmental requirements differ between the two species, the close proximity of diverse habitats (within pollinator range) has resulted in several cases of natural hybridization between the two. The result of the cross between these two distantly related species is a sterile perennial. Many of its characteristics are intermediate between its parents, but morphologically it is closer to Centaurea moncktonii (probably the maternal parent, and itself of hybrid origin). The plant could possibly become an invasive weed through clonal reproduction. The apparent maternal parent, which the hybrid may more closely resemble physiologically as well as morphologically, is a wellknown creeping weed in alpine pastures throughout Europe.
\end{abstract}

Key words: Centaurea moncktonii; Centaurea solstitialis; hybridization; invaders; Oregon.

\section{Resumen}

Nuevos hábitats, nuevas amenazas: Centaurea $x$ kleinii (C. moncktonii $x$ C. solstitialis), nueva especie híbrida entre dos malas hierbas invasoras.- La alteración antrópica del hábitat da paso a la cohabitación de especies importadas que nunca coexistirían en su ámbito natural. Centaurea solstitialis y Centaurea moncktonii son dos especies invasoras cuyas distribuciones en Eurasia apenas se solapan. Después de su introducción en Norteamérica, la expansión invasiva condujo a distribuciones superpuestas. Aunque los requerimientos ambientales de las dos especies son distintos, la proximidad de hábitats diversos (dentro del alcance de los polinizadores) ha dado lugar a varios casos de hibridación natural entre ambas. El cruce resultante entre dos especies lejanamente emparentadas es una planta perenne estéril. Muchos de los caracteres del híbrido son intermedios entre sus especies parentales, pero morfológicamente es más parecida a Centaurea moncktonii (probablemente la especie materna y a su vez ya de origen híbrido). La nueva especie podría convertirse en una mala hierba invasora gracias a su reproducción vegetativa. La que suponemos especie materna, a la cual el híbrido se acerca morfológicamente y puede que fisiológicamente, es una mala hierba rastrera bien conocida de las praderas alpinas en toda Europa.

Palabras clave: Centaurea moncktonii; Centaurea solstitialis; hibridación; invasoras; Oregón. 


\begin{abstract}
Resum
Nous hàbitats, noves amenaces: Centaurea x kleinii (C. moncktonii $x$ C. solstitialis), espècie nova híbrida entre dues males herbes invasores.- L'alteració antròpica de l'hàbitat dóna pas a la cohabitació d'espècies importades que mai coexistirien en el seu àmbit natural. Centaurea solstitialis i Centaurea moncktonii són dues espècies invasores les distribucions de les quals a Euràsia gairebé no se solapen. Després de la seva introducció a Amèrica del Nord, l'expansió invasiva va portar a distribucions superposades. Malgrat que els requeriments ambientals de les dues espècies són diferents, la proximitat d'hàbitats diversos (dins de l'abast dels pol-linitzadors) ha donat lloc a diversos casos d'hibridació natural entre ambdues. L' encreuament resultant entre dues espècies, llunyanament emparentades, és una planta perenne estèril. Molts dels caràcters de l'híbrid són intermitjos entre les seves espècies parentals, però morfològicament és més semblant a Centaurea moncktonii (probablement l'espècie materna, $\mathrm{i}$ al seu torn també d'origen híbrid). La nova espècie podria convertir-se en una mala herba invasora gràcies a la seva reproducció vegetativa. La que suposem espècie materna, a la qual l'híbrid s'acosta morfològicament i potser fisiològicament, és una mala herba prostrada ben coneguda de les pastures alpines a tota Europa.
\end{abstract}

Paraules clau: Centaurea moncktonii; Centaurea solstitialis; hibridació; invasores; Oregon.

\section{INTRODUCTION}

Worldwide plant migration has been greatly accelerated by human activities, especially farming and grazing of domestic livestock. One of the oldest examples is Centaurea cyanus L., associated with the cultivation of cereal grains since Neolithic times (Rösch, 1998). Although the development of herbicides reduced the impact of C. cyanus on crop yields, other species of Centaurea rank among the worst noncropland weeds in western North America: C. solstitialis L., C. diffusa Lam., C. stoebe L. (= C. maculosa Lam.), and C. moncktonii C.E. Britton (= C. pratensis Thuill. ${ }^{1}$ ) (Roché \& Roché, 1991a).

Invasion of new regions has brought species together that formerly were seldom (if ever) in close proximity. Some combinations (e.g., C. jacea L. $x C$. nigra L.) have long been widely known in Europe, and introduced in North America as hybrid swarms (more detail below). Other combinations believed until recently to be new (e.g., C. stoebe $x$ C. diffusa $=C$. $x$ psammogena Gáyer) were previously reported from their native ranges (Gáyer (1909) in Marrs et al., 2006; Ochsmann, 2000). Recent research suggests that the multiple introductions of $C$. diffusa included "admixed individuals" and that the hybrids were not newly created post-introduction (Blair \& Hufbauer, 2009). Other hybrids are entirely unexpected, because in addition to geographic separation, the taxa are only distantly related. That is the case with an apparent hybrid discovered in 1999 in southern Oregon, where $C$. moncktonii and $C$. solstitialis grow in close proximity (Fig. 1). Despite the improbability of this hybridization, some individuals were spotted as obvious intermediates between these two species.

According to Garcia-Jacas et al. (2006), both putative parents belong to the Centaurea Jacea clade that stands as the core group of Centaurea. However, in a geographic classification system, they segregate into two different clades. Centaurea moncktonii belongs to section Jacea, which is in the clade of widely distributed species. Centaurea solstitialis belongs to section Mesocentron among the Western Mediterranean group of species (Garcia-Jacas et al., 2006). Thus, despite sharing the important characters that define the Centaurea Jacea clade (pollen type Jacea and achene with a double pappus and lateral hilum), they are only distant relatives.

Based on multiple chromosome counts (Watanabe, 2010), C. moncktonii is a tetraploid with $2 n=4 x=44$ (as $C$. pratensis), while $C$. solstitialis is diploid with $2 n=16$. Probability of viable offspring from this cross should be extremely low. The apparent hybrid has been found in four separate locations (Fig. 1); the distance and lack of seed production indicate that the hybrids arose from independent crossings. Morphologically, the hybrid is similar to C. moncktonii, but with obvious traces of its $C$. solstitialis ancestry in the phyllary appendages, floret color, and indumentum of the vegetative parts.

\footnotetext{
${ }^{1}$ Centaurea pratensis Thuill. and $C$. debeauxii Gren. \& Godr. are among previous names widely used for the hybrid between C. nigra L. and C. jacea L., but according to Wagenitz (1980), the correct name for this species is C. moncktonii C. E. Britton.
} 


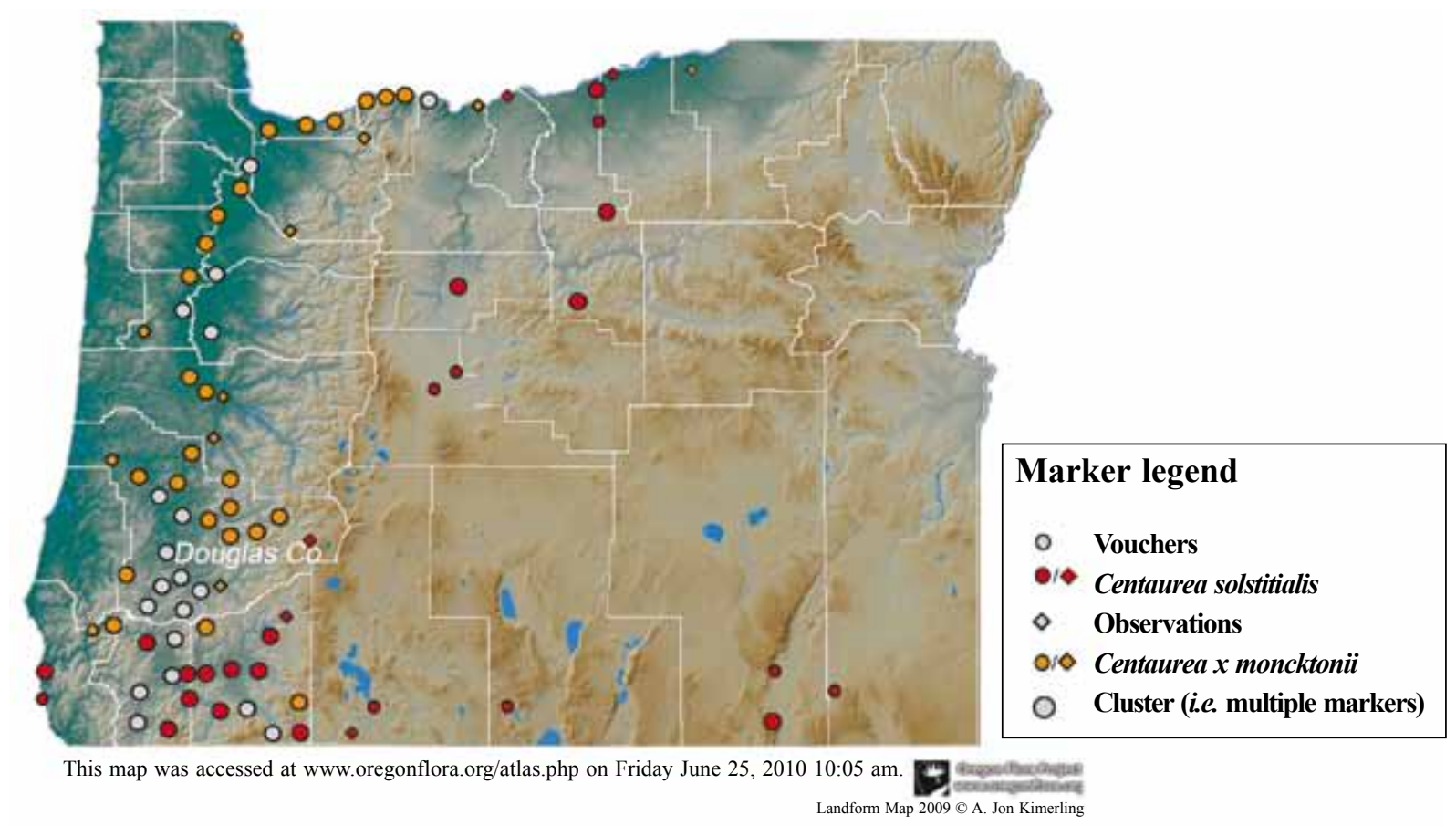

Figure 1. Distribution of Centaurea solstitialis (red dots), C. moncktonii (orange dots) and mixed populations (grey dots) in Oregon.

\section{Pollination}

Centaurea species in general are entomophilous (insect pollinated) and are visited by a wide range of species for pollen and/or nectar (Marsden-Jones \& Turrill, 1954). The disc florets containing the functional gynoecium and androecium are actinomorphic and gamopetalous; an insect visiting a capitulum during anthesis will push its proboscis successively into florets with open corollas. To collect pollen and nectar, an insect must deal with every floret separately, but it can pollinate many florets by crawling a very short distance, or by simply turning. Each floret has only one ovule requiring only one viable and compatible pollen grain to bring about fertilization (Marsden-Jones \& Turrill, 1954).

\section{Geographic distribution}

Centaurea solstitialis has a wide distribution along the Mediterranean region in its broadest sense, from Iran and Turkey to the Iberian Peninsula and North Africa. It originated in the Eastern Mediterranean, but has expanded to the entire Mediterranean region, usually associated with anthropic disturbance. As an alien invader, it has colonized extensive areas in the western USA, South America and Australia. Centaurea solstitialis became established in California in the mid-1800s and by 2000 infested more than four million hectares (Thomsen et al., 1996). It was first reported in Oregon in Douglas County in 1914 (Roché \& Talbott, 1986).

Centaurea moncktonii is a frequent and fully fertile hybrid between C. nigra and C. jacea. Centaurea nigra is native to the British Isles, with hybrids being common when $C$. jacea was introduced from the European Continent (Marsden-Jones $\&$ Turrill, 1954). Ockendon (1975) described the reverse situation in France and suggested that $C$. jacea is native and C. nigra introduced, which is much disputable following Dostál (1976). Because the F1 hybrid can back-cross with either parent and with other F1 individuals, hybrid swarms normally completely replace the pure forms. Both the parent species and the hybrid are common in Eurasia, becoming rare to the East.

The earliest reports of $C$. moncktonii in Oregon date to 1911 and 1918 in the Willamette Valley from Portland to Eugene (Roché \& Talbott, 1986). Howell (1959) reported that meadow knapweed 
(C. moncktonii) was cultivated for winter forage near Roseburg (Douglas County), where it remains abundant today. It is leafier and more palatable to livestock than other knapweeds, but as plants mature, both palatability and nutritional value decline (Roché \& Roché, 1991b).

\section{Ecological distribution}

In its native range, $C$. soltitialis seldom grows in the mountains, being restricted to the Mediterranean climate of its origin. In western North America, its distribution is also correlated to Mediterranean climates, with the most aggressive invasion in California. In the more northern latitudes (e.g., Washington State, ca. $46^{\circ}$ to $49^{\circ}$ North), it is restricted to sunny, warm habitats such as south slopes at lower elevations, and despite repeated introductions, does not persist in British Columbia, Canada (Roché \& Thill, 2001). In Oregon, it is most competitive in the Mediterranean climate of the inland valleys between the Cascade and Coast Range mountains (a small, northern extension of the Central Valley of California), the warm basalt slopes in the Columbia Gorge, and south slopes in the foothills of the Blue Mountains.

According to most of the monographers (e.g., Marsden-Jones \& Turrill, 1954; Wagenitz, 1987), C. moncktonii is a meadow plant and in the Mediterranean region it grows only in the moistest places in the mountains. In western North America, $C$. moncktonii extends from coastal northern California through Oregon and Washington into British Columbia, primarily in moist forested regions and in meadows, irrigated pastures, and riparian zones (Roché \& Johnson, 2003). The largest populations of C. moncktonii in Oregon are in the interior valley lowlands (Umpqua and Willamette Valleys) including both the east slopes of the Coast Range and the west slopes of the Cascade Range. In Douglas County the Klamath Range forms a mountain bridge between the Coast and Cascade Ranges; annual precipitation ranges from $840 \mathrm{~mm}$ in the lowland valleys to over $1300 \mathrm{~mm}$ in the foothills (Johnson et al., 2003). Substantial populations also grow on the mesic eastern slopes and valleys of the Cascade Range near Hood River in the Columbia River Gorge in northern Oregon.

Contact between C. moncktonii and C. solstitialis within the range of their native distribution is infrequent because their ecological requirements differ so greatly. What differs in southern Oregon is not the biology of the plants, but that appropriate habitats occur within flight range of their pollinators. Both species share disturbed sites on roadsides that are adjacent to mesic meadows and riparian zones that support C. moncktonii and warm south-facing slopes that are dominated by $C$. solstitialis.

\section{Description}

Centaurea x kleinii C. Roché \& Susanna, nothospecies nova.

Ad Centaurea pratense accedens sed planta humilior capitulis minoribusque, bracteis in appendice triangulari pectinato-fimbriato nec non lacerato- pectinato productis. A C. solstitiali habitu perenne, bracteis in breve mucro haud spinescente abeuntibus, flosculis albidis vel palliditer roseis nec non luteis differt.

Species Jeanne Klein, qui novum hybridum comunicavit et primum invenit, gratissimo animo dicata.

Holotype in herbario horti botanici barcinonensi (BC 840640, Fig. 2): "PLANTS OF SOUTHWESTERN OREGON / BLM - Medford District Herbarium / Asteraceae / Centaurea $x$ pratensis $x$ Centaurea solstitialis / Curry Co., OR: Wild \& Scenic Rogue River. / Quail Creek. sandy loam soil, old roadbed. / T33S R10W Sect. 12 SE $1 / 4$ of the SW $1 / 4$. Elevation $400 \mathrm{ft}$. / $42^{\circ} 42^{\prime} 38^{\prime \prime}$ N. Lat. $123^{\circ} 49^{\prime} 50^{\prime \prime}$ W. Long. / found as single plant, abundant yellow starthistle at site, / meadow and diffuse knapweed observed along the river at / not too distant locations. // Robert Budesa 29 July 2001."

Other materials examined: Douglas County, Oregon: Cow Creek Road, approximately 20 miles southwest of city of Riddle. Growing along roadside between road and Cow Creek. Elev. $290 \mathrm{~m}$. $42^{\circ} 50.303^{\prime}$ N. Lat. $123^{\circ} 37.204^{\prime}$ W. Long. Associated species: Pseudotsuga menziesii, Rubus discolor, Cytisus scoparius, Centaurea pratensis, Centaurea solstitialis, Daucus carota, Eschscholzia californica, Avena barbata. Leg. Jeanne M. Klein; 07 September 2000 (BLM, Medford District Herbarium). Douglas County, Oregon: Myrtle Island, near Tyee. $42^{\circ} 28.426^{\prime} \mathrm{N}$ Lat. $123^{\circ} 32.373^{\prime}$ 'W Long. [T24S R7W Sec. 20] On leading edge of the island in cobbles and sandy soil. Elev. $70 \mathrm{~m}$. Associated species: Centaurea pratensis, Centaurea solstitialis, Rubus discolor, Chondrilla juncea. Leg. Jeanne 


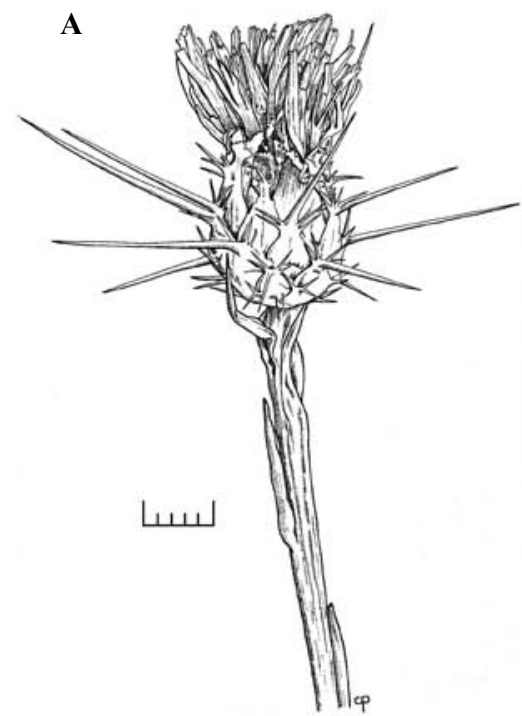

D

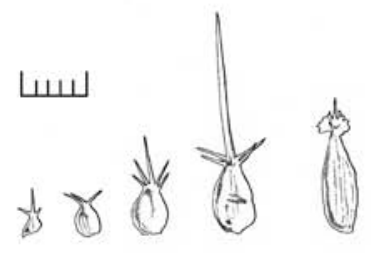

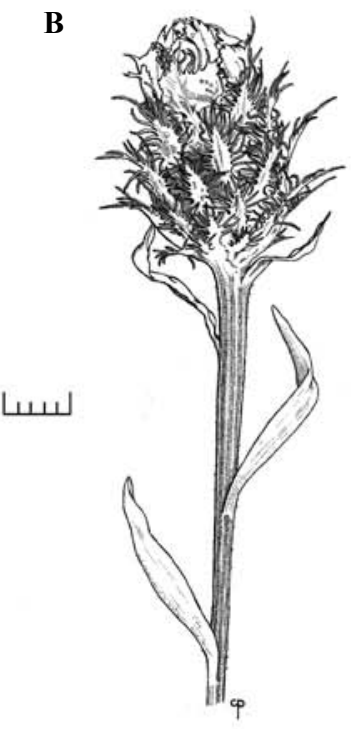

C

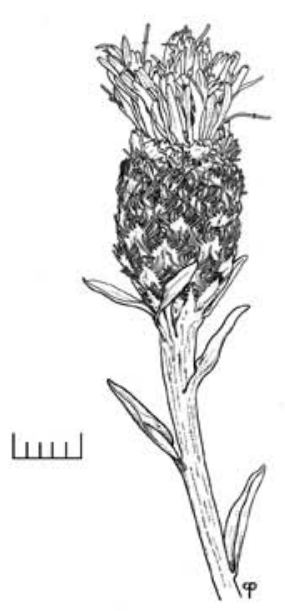

$\mathbf{E}$

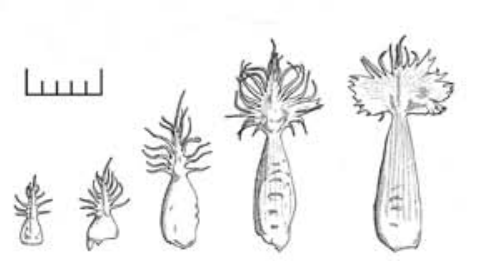

F

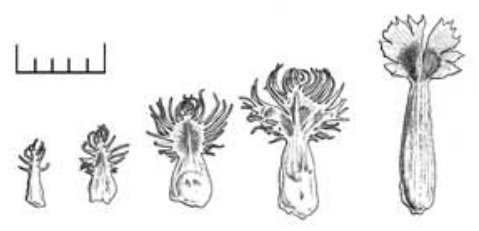

Figure 2. Drawings of the capitulum and detail of the bracts (from outermost to innermost) of Centaurea solstitialis (A and D), C. $x$ kleinii (B and E) and C. moncktonii (C and F). Scale: $5 \mathrm{~mm}$ in all the cases. Drawings by Carles Puche.

Klein \& Pete Figura; 20 July 1998 (BLM, Medford District Herbarium). Douglas County, Oregon: Island Creek BLM Day Use Area, along Cow Creek Road. Elev. 230 m. $42^{\circ} 54.772^{\prime}$ N. Lat. $123^{\circ} 28.938^{\prime}$ W. Long. Growing along roadside with Vulpia myuros, Aira caryophyllea, Cynosurus echinatus, Madia sp., Pinus ponderosa, Rubus discolor, Centaurea solstitialis, Centaurea pratensis. Cindy Roché \& Jeanne Standley; 28 July 2003 (BLM, Medford District Herbarium).

Perennial herb $60-150 \mathrm{~cm}$ high. Basal leaves entire, lanceolate, to $8 \mathrm{~cm}$. Middle and upper leaves entire, floccose, densely glandular, ash-green. Stem striate, much-branched, woolly. Capitula heterogamous, 15-20 mm broad, cylindrical (Fig. 3B). Bracts in five rows (Fig. 3E); outer and middle ones nervose, with a straw-coloured triangular appendage, 3-4 $\mathrm{mm}$ long x 2-3 $\mathrm{mm}$ wide, pectinatefimbriate, ending in a very short $(1 \mathrm{~mm})$ non-spiny mucro; fimbriae minutely denticulate. Inner bracts with an oval scariose appendate, lacerate-pectinate, mucronate; innermost ones linear with a cucullate appendage. Outer florets large and radiant, sterile. Inner florets yellowish when dry, probably whitish or cream-white. Achenes not seen, possibly aborted.

The new species is intermediate in most of its characters between C. solstitialis (Figs. 3A, D) and C. moncktonii (Figs. 3C, F), but the habit is more similar to $C$. moncktonii.

\section{Potential weediness}

The new hybrid is morphologically much closer to $C$. moncktonii. It is sterile, producing neither seeds nor viable pollen (Carol Mallory-Smith, pers. comm.). In its current form it could show weedy behavior as a perennial herb only through clonal reproduction. Centaurea solstitialis spreads solely by seed, but root and crown fragments of $C$. moncktonii regrow when disturbed by heavy equipment or cultivation 


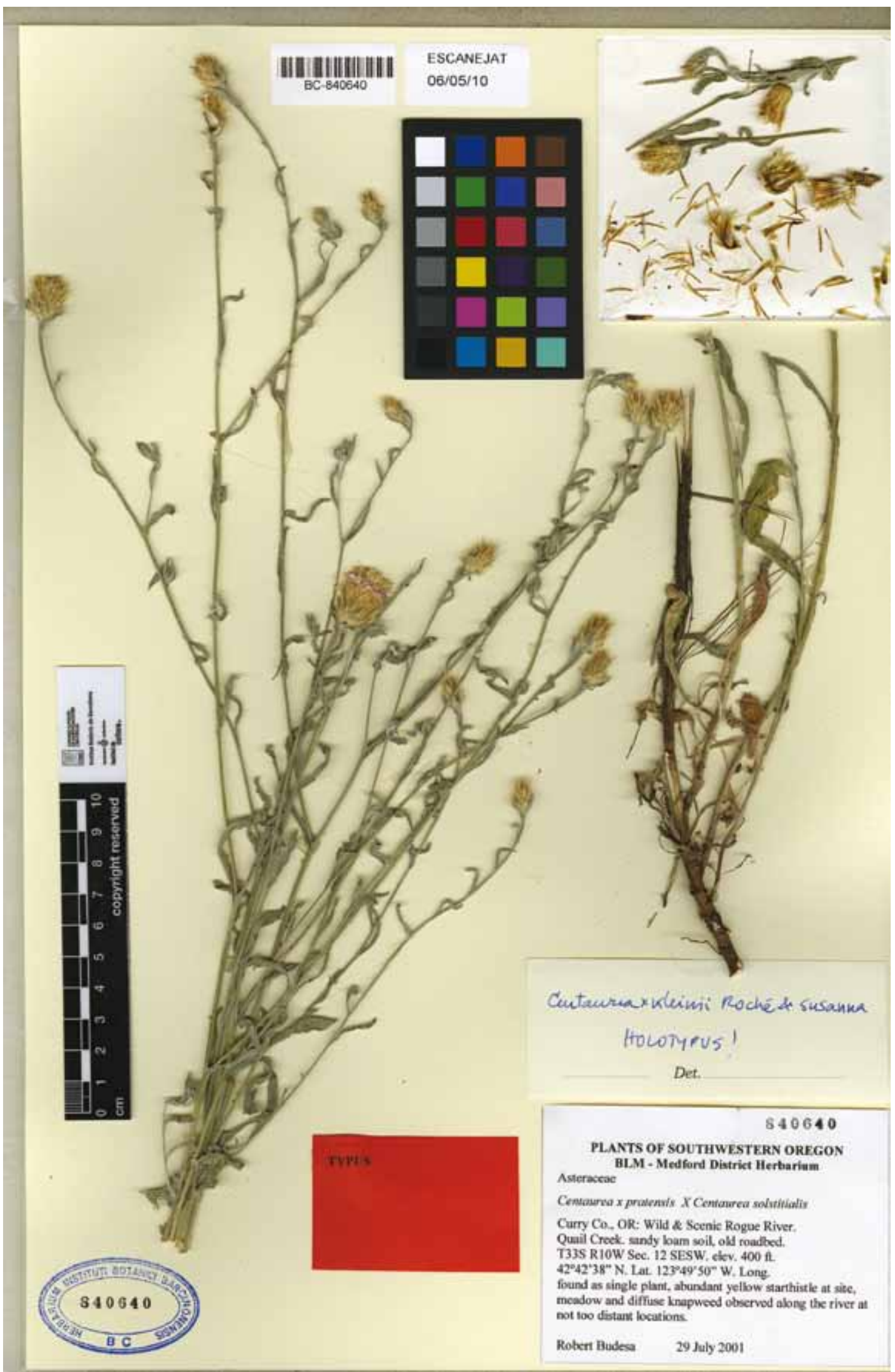

Figure 3. Holotype of Centaurea x kleinii (herbarium BC). 
(Roché \& Johnson, 2003). Alternatively, this sterile hybrid may be one mutation away from becoming a "super weed." Crupina intermedia Walp. is a robust weedy invader that arose when $C$. crupinastrum Vis. $(2 n=28)$ hybridized with $C$. vulgaris $(2 n=30)$ and subsequently became tetraploid with $2 n=4 x=58$ (Couderc, 1975). A parallel scenario for Centaureax kleinii could yield a fertile hybrid with exceptional vigor $(2 n=6 x=60)$.

\section{ACKNOWLEDGEMENTS}

Jeanne Standley provided information for known sites of the hybrid. Carol Mallory-Smith, Oregon State University, has maintained a small population in cultivation for six years and provided information on infertility. The Oregon Flora Project Atlas provided the distribution map for $C$. solstitialis and $C$. moncktonii in Oregon. Carles Puche made the excellent illustrations of Fig. 1.

\section{REFERENCES}

Blair, A. C. \& Hufbauer, R. A. 2009. Hybridization and invasion: one of North America's most devastating invasive plants shows evidence for a history of interspecific hybridization. Evol. Appl. 3: 40-51.

Couderc, M. 1975. Origine hybride du Crupina intermedia Briq. et Cavill. Colloq. Int. C.N.R.S. 235: 531-536.

Dostál, J. 1976. Centaurea L. In: Tutin, T. G., Heywood, V. H., Burges, N. A., Moore, D. M., Valentine, D. H., Walters, S. M. \& Webb, D. A. (Eds.), Flora Europaea 4. Cambridge University Press, London, New York and Melbourne: 254-301.

Gáyer, G. 1909. Vier neue Centaureen der Flora von Ungarn. Magyar Bot. Lapok. 8: 58-61.

Garcia-Jacas, N., Uysal, T., Romashchenko, K., SuárezSantiago, V., Ertuğrul, K. \& Susanna, A. 2006. Centaurea revisited: a molecular survey of the Jacea group. Ann. Bot. (Oxford) 98: 741-753.

Howell, J. T. 1959. Distributional data on weedy thistles in western North America. Leafl. West. Bot. 9: 17-32.

Johnson, D., Vandenkoornhuyse P. J., Leake, J. R., Gilbert, L., Booth, R. E, Grime, J. P., Young, P. W. \& Read, D. J. 2003. Plant communities affect arbuscular mycorrhizal fungal diversity and community composition in grassland microcosms. New Phytol. 161: 503-515.

Keil, D. J. \& Ochsmann, J. 2006. Centaurea. In: Flora of North America Editorial Committee (Eds.), Flora of North America North of Mexico. Oxford University Press, New York: 181-194.

Marrs, R. A., Hufbauer, R. A., Bogdanowicz, S. M. \& Sforza, R. 2006. Nine polymorphic microsatellite markers in Centaurea stoebe L. [subspecies C. s. stoebe and C. s. micranthos (S. G. Gmelin ex Gugler) Hayek] and C. diffusa Lam. (Asteraceae). Molec. Ecol. Notes 6: 897-899.

Marsden-Jones, E. M. \& Turrill, W. B. 1954. British knapweeds. A study in synthetic taxonomy. Ray Society, London.

Ochsmann, J. 2000. Morphologische und molekularsystematische Untersuchungen an der Centaurea stoebe L.-Gruppe (Asteraceae-Cardueae) in Europa. Dissertationes Botanicae 324. J. Cramer, Vaduz.

Ockendon, D. J. 1975. Centaurea. In: Stace, C. A. (Ed.), Hybridization and the flora of the British Islands. Academic Press, London: 427-428.

Roché, B. F., Jr. \& Talbott, C. J. 1986. The collection history of Centaureas found in Washington state. Ag. Res. Ctr. Bull. XB0978, Washington State University, Pullman.

Roché, B. F., Jr. \& Roché, C. T. 1991a. Identification, introduction, distribution, ecology, and economics of Centaurea species. In: James, L. F., Evans, J. O., Ralphs, M. E. \& Childs, R. D. (Eds.), Noxious range weeds. Westview, Boulder: 274-291.

Roché, C. T. \& Roché, B. F., Jr. 1991b. Meadow knapweed invasion in the Pacific Northwest, U.S.A., and British Columbia, Canada. Northw. Sci. 65: 53-61.

Roché, C. T. \& Thill, D. C. 2001. Biology of common crupina and yellow starthistle, two Mediterranean winter annual invaders in western North America. Weed Sci. 49: 439-447.

Roché, C. T. \& Johnson, D. E. 2003. Meadow Knapweed (Centaurea pratensis Thuill.). PNW Ext. Bull. 0566. Oregon State University, Corvallis.

Rösch, M. 1998. The history of crops and crop weeds in southwestern Germany from the Neolithic period to modern times, as shown by archaeobotanical evidence. Veg. Hist. Archaeobot. 7: 109-125.

Thomsen, C. D., Williams, W. A., Vayssieres, M. P., Turner, C. E. \& Lanini, W. T. 1996. Yellow starthistle biology and control. University of California Publication 21541, Oakland.

Wagenitz, G. 1987. Centaurea. In: Hegi, G. (Ed.), Illustrierte Flora von Mittel-Europa VI 4. Verlag Paul Parey, Berling and Hamburg: 934-985.

Watanabe, K. 2010. Index to chromosome numbers in Asteraceae. Retrieved Jun 10, 2010, from http: //www-asteraceae. cla.kobe-u.ac.jp/index.htmlm. 